\title{
Innovative Development Of Agricultural Enterprises As An Economic System
}

\author{
Iryna Koshkalda* \\ Department of Land Administration \\ and Cadastre \\ Dokuchayev Kharkiv National \\ Agrarian University \\ Kharkiv, Ukraine \\ irinavit1506@gmail.com
}

\author{
Alona Riasnianska \\ Department of Business, Trade and \\ Exchange Activity \\ Petro Vasylenko Kharkiv National \\ Technical University of Agriculture \\ Kharkiv, Ukraine \\ alona.ryasnyanska@gmail.com \\ Olena Dombrovska \\ Department of Land Administration \\ and Cadastre \\ Dokuchayev Kharkiv National \\ Agrarian University \\ Kharkiv, Ukraine \\ domolena73@gmail.com
}

\author{
Olha Dankeyeva \\ Department of Land Management and \\ Cadastre \\ Lugansk National Agrarian University \\ Starobelsk, Ukraine \\ dankeeva.olga@gmail.com
}

\begin{abstract}
The transformations that are currently taking place in the world economic system are forcing scientists to research the factors that allow national economic systems to be sustainable and competitive in today's realities. The key direction for Ukraine with its fertile black soil is the innovative development of the economy as a whole and enterprises, especially agricultural, in particular. The article analyzes the innovative development of enterprises in Ukraine, the quantitative indicators of recent years in terms of innovative development and financing and investment in innovative development of enterprises. It is suggested to consider agricultural enterprises an economic system to explore in more detail their innovative development, the factors that influence it, the methods of its improvement, and more. The specific features of agricultural enterprises as an economic system are emphasized, in particular, their strategic role in terms of food security, their key importance for rural areas and rural population. There are two main directions of innovative development of agricultural enterprises: improvement of production technologies and improvement of quality of labor resources. The importance of labor resources for the effects of the functioning of agricultural enterprises is emphasized. The authors of the article have proposed a methodological approach to material incentives for the staff at agricultural enterprises and adapted it to a specific agricultural enterprise.
\end{abstract}

Keywords - innovative development, agricultural enterprise, economic system, labor resources

\section{INTRODUCTION}

Today, there are fundamental changes in the international economic system. The national economy can only be competitive if the technical, technological, and intellectual potential of Ukraine is enhanced. Innovative development of entrepreneurship and attraction of investment resources for financing research and educational programs is a strategic direction for innovative development of the state.
Enterprise as an economic system is a set of interconnected and ranked elements that are in a stable relationship to ensure their functioning and development as an integral unit for receiving profit.

Malik M. I. emphasizes that the activity of any enterprise is based on the principles of entrepreneurship. He defines entrepreneurship as an institute for providing innovative development of the agrarian sector of the economy, which serves as a means of structural adjustment, an incentive for transformational changes through the institutionalization of economic relations to fit market conditions [1].

Providing innovative development of domestic enterprises is a key prerequisite for their growth and entrance to international markets in a globally competitive environment, as suggested by global economic trends [2] [9].

To ensure the innovative development of agricultural enterprises as an economic system, an important part is given to the improvement of such an element as labor resources. The determining factor is the motivation of employees. Irving B. Weiner argues that work motivation is the driving force that creates the excitement of one's work so that they will cooperate, work effectively and integrate with all their efforts to achieve satisfaction [10]. "Several factors can affect employees' motivation. In recent research, the relationship between job satisfaction, motivation and low burnout levels among employees has been verified" [11]. Also mentoring can positively contribute to career development and motivation, especially in the case of new employees [12].

Wasito, E. explains the influence of material incentives on motivation has a significant influence, where the higher the incentive given the company, the higher the motivation of his work [13]. Material incentives are one of the company's financial compensation beyond the basic salary 
that employees receive on their performance. The Company believes that the system of compensation in general and the material incentive system, in particular, affects the motivation of employees in doing their work [14].

\section{THE AIM AND METHOD USED}

Ukraine ranks 47th out of 129 countries in the Global Innovation Index, with a clear positive trend in recent years: 47th in 2017, 56th in 2016, 64th in 2015, in 2014 it was 63rd. Switzerland ranks first and Yemen is the last (129th). In particular, according to the indicator of favorable political environment, the authors ranked Ukraine 110th, in terms of ecological sustainability 120th, and creation of new knowledge and intangible assets -17 th [15]. This means that our country and its human resources have very high intellectual potential and the main problem in this area is the lack of funding and investment.

According to the calculations of the State Statistics Service of Ukraine, in 2018, the share of total expenditure on research and development in GDP was $0.47 \%$, including the expenses of the state budget $-0.17 \%$. According to 2017 data, the share of expenditure on research in the GDP of EU-28 countries averaged $2.06 \%$. The average share of $R \& D$ expenditure was higher in Sweden - 3.4\%, Austria - 3.16\%, Denmark - 3.05\%, Germany $-3.02 \%$, Finland $-2.76 \%$, Belgium $-2,58 \%$, France $-2,19 \%$; it was lower in Romania, Latvia, Malta, Cyprus and Bulgaria (from $0.5 \%$ to $0.75 \%$ ) [16].

According to the State Statistics Service of Ukraine, during 2014-2016, the share of enterprises engaged in innovation activity was rather small, about $18.4 \%$, including technological innovations - $11.8 \%(5.7 \%$ product and 10.3 - processional), non-technological $13,4 \%(8,7 \%$ - organizational and $10,2 \%$ - marketing $)$ [16].

Buying machinery, equipment and software remain a priority area of the innovation spending - in 2016, almost $70 \%$ of the total innovative cost of the enterprise was for the purchase of machinery, equipment, and software, $15.0 \%$ on the implementation of internal R\&D and $9.1 \%$ for the acquisition of external R\&D. In 2016, expenditures for innovation were mainly made at own expense of enterprises ( $89.5 \%$ of the total volume of financing), funds of foreign investors (3.1\%) and other sources (2.9\%) [17]

Agricultural enterprises are particularly important for Ukraine with its fertile black soil, and globally, in terms of food security, since many significant scientific studies are conducted in the agricultural sector, but most of them cannot be implemented due to insufficient funding and investment. However, there is a tendency to increase capital investment in agriculture as a whole: more than three times - from UAH 18582.4 million in 2014 to UAH 64084.1 million in 2017; as well as capital investments in intangible assets, including innovations: more than 8 times - from UAH 75.5 million in 2014 to UAH 608.2 million in 2017 [18].

According to World Bank analysts, the economies of developed countries, in particular, the GDP index of $80 \%$ directly depends on the quality of labor potential and only $20 \%$ account for its productive component. World Bank statistics based on surveys in more than 160 countries show that significant economic achievements contain $20 \%$ of natural capital, $16 \%$ of real physical capital, and $60 \%$ of human capital. Analyzing the structure of costs of average Ukrainian enterprises, as well as the organization of their production, we can conclude that little attention is paid to both the intellectualization of labor in the production process and the cost of improving intellectual capital [19].

Ensuring the constant development of personnel at the enterprise is possible under the conditions of functioning of an effective motivational mechanism, which formulation is largely determined by the role of managerial personnel in the process of making and implementing managerial decisions. The manager in one way or another influences the employee's value orientations, his motivation, group interaction, and moral environment.

The method used in conducting research using descriptive and verification research methods. In the study, we used the methodology of conducting research based on Delphi collective expert evaluations. The research hypothesis is the impact of the proposed factors of employment on the material incentives for employees. There are the following factors: 1) professional development; 2) level of responsibility; 3) work experience allowance; 4) allowance for the return on assets; 5) labor intensity; 6) allowance for urgency, quality of work; 7) scarcity of professions. Experts (32 respondents) were the employees of agricultural enterprises.

Expert evaluation of the relative importance of factors is carried out by assigning them a number of points within the range from 0 to 100 . Zero is for the factor, which in the expert's opinion is not significant; 100 points are for the factor that is the most significant or crucial.

When processing materials of collective peer review of the relative weight of individual factors, ranks are used along with scores. Therefore, the data obtained in points are ranked accordingly. The order number that determines the position of each factor in the totality of factors is called rank. Usually the ranks correspond to the natural numbers $1,2,3, \ldots, \mathrm{n}$, where $\mathrm{n}$ is the number of ranked factors.

A rank equal to one is assigned to the most important factor; rank with the number $\mathrm{n}$ is the least important factor. If an expert gives the same number of points to several factors, then others are assigned standardized ranks. Standardized rank is the proportion of the sum of rankings with the factors of equal rank to the total number of such alternatives.

The evaluation of the degree of consistency of the experts' opinions is evaluated by the coefficient of concordance.

\section{RESEARCH RESULTS}

Any resource should perform maximum efficiency. Today, enterprises should be provided with skilled workers, including managers, and the latter should possess the qualities to contribute to improving labor productivity. That is, every agricultural enterprise must have a system of study and additional training, providing additional study 
and occupational study, providing training and seminars, taking into account the specific features of the activity. It is important to strengthen the links between the basic enterprises and the teaching staff of the agrarian university and relevant research stations. This gives some advantages, in particular, enterprises are allowed to train their employees on a university basis; educational institutions have the opportunity to send graduates to work (internships, internships) at agricultural enterprises.

According to the methodology of the research based on Delphi expert evaluation, the point scores are put in a separate matrix, which is presented in Table 1.

TABLE I. MATRIX OF POINTS GIVEN BY EXPERTS TO FACTORS THAT SHAPE THE LEVEL OF MATERIAL INCENTIVES

\begin{tabular}{|c|c|c|c|c|c|c|c|}
\hline \multirow[b]{2}{*}{ 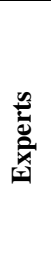 } & \multicolumn{7}{|c|}{ Factors } \\
\hline & 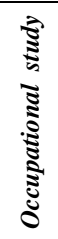 & 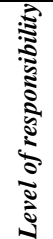 & 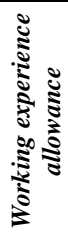 & 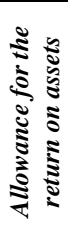 & 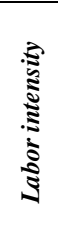 & 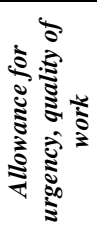 & 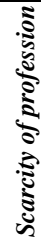 \\
\hline 1 & 80 & 70 & 100 & 60 & 90 & 80 & 40 \\
\hline 2 & 70 & 60 & 80 & 60 & 80 & 70 & 50 \\
\hline 3 & 80 & 70 & 100 & 30 & 90 & 90 & 40 \\
\hline 4 & 80 & 90 & 100 & 40 & 90 & 70 & 50 \\
\hline 5 & 90 & 60 & 70 & 40 & 100 & 70 & 40 \\
\hline 6 & 80 & 80 & 80 & 30 & 100 & 70 & 70 \\
\hline 7 & 80 & 80 & 90 & 60 & 70 & 80 & 30 \\
\hline 8 & 80 & 60 & 80 & 70 & 80 & 60 & 60 \\
\hline 9 & 90 & 60 & 70 & 40 & 80 & 90 & 30 \\
\hline 10 & 80 & 80 & 100 & 20 & 80 & 70 & 50 \\
\hline 11 & 100 & 90 & 60 & 70 & 80 & 60 & 70 \\
\hline 12 & 80 & 50 & 70 & 40 & 80 & 70 & 60 \\
\hline 13 & 80 & 60 & 90 & 40 & 80 & 80 & 50 \\
\hline 14 & 80 & 80 & 60 & 50 & 100 & 70 & 30 \\
\hline 15 & 70 & 70 & 50 & 40 & 90 & 70 & 30 \\
\hline 16 & 100 & 80 & 90 & 70 & 80 & 90 & 20 \\
\hline 17 & 70 & 70 & 80 & 40 & 80 & 60 & 40 \\
\hline 18 & 80 & 60 & 80 & 50 & 80 & 70 & 40 \\
\hline 19 & 70 & 70 & 100 & 50 & 80 & 80 & 50 \\
\hline 20 & 80 & 60 & 90 & 60 & 100 & 60 & 60 \\
\hline 21 & 80 & 100 & 80 & 30 & 100 & 60 & 50 \\
\hline 22 & 60 & 90 & 90 & 60 & 80 & 70 & 50 \\
\hline 23 & 50 & 70 & 70 & 40 & 80 & 80 & 50 \\
\hline 24 & 80 & 80 & 80 & 60 & 80 & 70 & 40 \\
\hline 25 & 100 & 70 & 100 & 70 & 70 & 100 & 40 \\
\hline 26 & 80 & 50 & 100 & 30 & 70 & 70 & 50 \\
\hline 27 & 90 & 60 & 90 & 60 & 100 & 70 & 30 \\
\hline 28 & 90 & 40 & 80 & 100 & 60 & 70 & 40 \\
\hline 29 & 80 & 70 & 90 & 20 & 90 & 90 & 60 \\
\hline 30 & 50 & 50 & 70 & 60 & 70 & 80 & 40 \\
\hline 31 & 70 & 70 & 80 & 50 & 60 & 60 & 50 \\
\hline 32 & 80 & 80 & 80 & 40 & 80 & 70 & 50 \\
\hline
\end{tabular}

Let us introduce the following conventions: $m$ is the number of experts participated in the collective peer review; $1,2,3, \ldots$, and $, \ldots, m$ are possible expert numbers; $\mathrm{n}$ is the number of factors being studied and proposed for the evaluation; $1,2,3, \ldots$, and, .., $n$ are possible numbers of the studied factors; $\mathrm{mj}$ is the number of experts having evaluated the $j$-th factor; $C_{i j}$ is the evaluation of the relative weight (in points) provided by the $i$-th expert of the $j$-th factor; $R_{i j}$ is the rank given by the $j$-th expert of the $j$-th factor.
Table 2 shows an example of ranking of indicators based on the experts' point evaluation of individual factors from 1 and 30. Ranking of answers of other experts is carried out in the same way.

TABLE II. RANKING OF INDICATORS BASED ON THE SCORE OF POINTS

\begin{tabular}{|c|c|c|c|c|c|c|c|}
\hline \multirow{2}{*}{ Indicators } & \multicolumn{7}{|c|}{ Factors } \\
\cline { 2 - 9 } & $\mathbf{1}$ & $\mathbf{2}$ & $\mathbf{3}$ & $\mathbf{4}$ & $\mathbf{5}$ & $\mathbf{6}$ & $\mathbf{7}$ \\
\hline Score of points (1) & 80 & 70 & 100 & 60 & 90 & 80 & 40 \\
\hline Rank & $3-4$ & 5 & 1 & 6 & 2 & $3-4$ & 7 \\
\hline Standardized rank & 3,5 & 5 & 1 & 6 & 2 & 3,5 & 7 \\
\hline Score of points (30) & 50 & 50 & 70 & 60 & 70 & 80 & 40 \\
\hline Rank & $5-6$ & $5-6$ & $2-3$ & 4 & $2-3$ & 1 & 7 \\
\hline Standardized rank & 5,5 & 5,5 & 2,5 & 4 & 2,5 & 1 & 7 \\
\hline
\end{tabular}

Standardized ranks are obtained as follows: $3,5=(3+$ 4) $: 2 ; 5,5=(5+6): 2 ; 2,5=(2+3): 2$.

According to the matrix of points, the ranking of factors is carried out, which results are presented in the matrix of ranks (Table 3).

TABLE III. MATRIX OF EXPERTS'RANKINGS OF THE FACTORS THAT SHAPE THE LEVEL OF MATERIAL INCENTIVES

\begin{tabular}{|c|c|c|c|c|c|c|c|}
\hline \multirow[b]{2}{*}{$\sum_{\substack{a \\
\hdashline}}^{n}$} & \multicolumn{7}{|c|}{ Factors } \\
\hline & 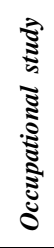 & 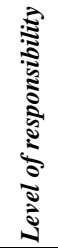 & 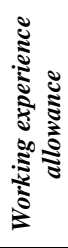 & 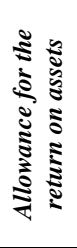 & 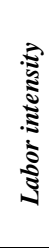 & 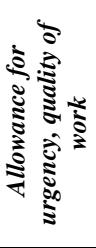 & 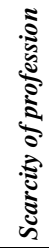 \\
\hline 1 & 3,5 & 5 & 1 & 6 & 2 & 3,5 & 7 \\
\hline 2 & 3,5 & 5,5 & 1,5 & 5,5 & 1,5 & 3,5 & 7 \\
\hline 3 & 4 & 5 & 1 & 7 & 2,5 & 2,5 & 6 \\
\hline 4 & 4 & 2,5 & 1 & 7 & 2,5 & 5 & 6 \\
\hline 5 & 2 & 5 & 3,5 & 6,5 & 1 & 3,5 & 6,5 \\
\hline 6 & 3 & 3 & 3 & 7 & 1 & 5,5 & 5,5 \\
\hline 7 & 3 & 3 & 1 & 6 & 5 & 3 & 7 \\
\hline 8 & 2 & 3 & 2 & 4 & 2 & 3 & 3 \\
\hline 9 & 1,5 & 5 & 4 & 6 & 3 & 1,5 & 7 \\
\hline 10 & 3 & 3 & 1 & 7 & 3 & 5 & 6 \\
\hline 11 & 1 & 2 & 6,5 & 4,5 & 3 & 6,5 & 4,5 \\
\hline 12 & 1,5 & 6 & 3,5 & 7 & 1,5 & 3,5 & 5 \\
\hline 13 & 3 & 5 & 1 & 7 & 3 & 3 & 6 \\
\hline 14 & 2,5 & 2,5 & 5 & 6 & 1 & 4 & 7 \\
\hline 15 & 3 & 3 & 5 & 6 & 1 & 3 & 7 \\
\hline 16 & 1 & 4,5 & 2,5 & 6 & 4,5 & 2,5 & 7 \\
\hline 17 & 3,5 & 3,5 & 1,5 & 6,5 & 1,5 & 5 & 6,5 \\
\hline 18 & 2 & 5 & 2 & 6 & 2 & 4 & 7 \\
\hline 19 & 4,5 & 4,5 & 1 & 6,5 & 2,5 & 2,5 & 6,5 \\
\hline 20 & 3 & 5,5 & 2 & 5,5 & 1 & 5,5 & 5,5 \\
\hline 21 & 3,5 & 1,5 & 3,5 & 7 & 1,5 & 5 & 6 \\
\hline 22 & 5,5 & 1,5 & 1,5 & 5,5 & 3 & 4 & 7 \\
\hline 23 & 5,5 & 3,5 & 3,5 & 7 & 1,5 & 1,5 & 5,5 \\
\hline 24 & 2,5 & 2,5 & 2,5 & 6 & 2,5 & 5 & 7 \\
\hline 25 & 2 & 5 & 2 & 5 & 5 & 2 & 7 \\
\hline 26 & 2 & 5,5 & 1 & 7 & 3,5 & 3,5 & 5,5 \\
\hline 27 & 2,5 & 5,5 & 2,5 & 5,5 & 1 & 4 & 7 \\
\hline 28 & 2 & 6,5 & 3 & 1 & 5 & 4 & 6,5 \\
\hline 29 & 4 & 5 & 2 & 7 & 2 & 2 & 6 \\
\hline 30 & 5,5 & 5,5 & 2,5 & 4 & 2,5 & 1 & 7 \\
\hline 31 & 2,5 & 2,5 & 1 & 6,5 & 4,5 & 4,5 & 6,5 \\
\hline 32 & 2,5 & 2,5 & 2,5 & 7 & 2,5 & 5 & 6 \\
\hline
\end{tabular}

The sum of ranks is calculated for all factors and it increases as the relative importance of the studied factors 
decreases. The average rank assigned by the experts of the $j$-th factor is determined by the formula (1):

$$
S_{j}=\frac{\sum_{i=1}^{m} R_{i j}}{m}
$$

Concurrently, an average value in the formula (2) is calculated for each investigated factor alongside with the average ranks:

$$
\mathrm{M}_{j}=\frac{\sum_{i=1}^{m} \mathrm{C}_{i j}}{m}
$$

The greater the value of $M_{j}$, the higher, according to the experts, the relative importance of the factor. The smaller the rank, the more important the factor is.

Let us calculate the indicators of the relative importance of the factors that shape the level of material incentives (Table 4).

TABLE IV. INDICATORS OF THE RELATIVE IMPORTANCE OF

\begin{tabular}{|c|c|c|c|c|c|c|c|}
\hline \multirow[b]{2}{*}{ Indicators } & \multicolumn{7}{|c|}{ Factors } \\
\hline & 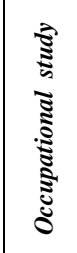 & 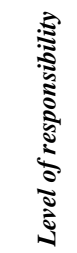 & 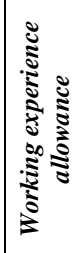 & 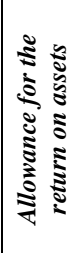 & 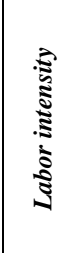 & 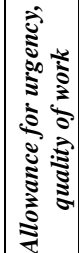 & 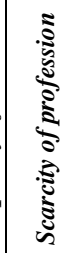 \\
\hline $\begin{array}{l}\text { Factual total } \\
\text { points }\left(\sum C_{i j}\right)\end{array}$ & 2530 & 2230 & 2650 & 1580 & 2650 & 2350 & 1460 \\
\hline $\begin{array}{l}\text { Average points } \\
\left(M_{j}\right)\end{array}$ & 79,1 & 69,7 & 82,8 & 49,4 & 82,8 & 73,4 & 45,6 \\
\hline $\begin{array}{c}\text { Total ranks } \\
\left(\sum R_{i j}\right)\end{array}$ & 94,5 & 128,5 & 76,5 & 191,5 & 79 & 117 & 200 \\
\hline $\begin{array}{c}\text { Average rank } \\
\left(S_{i}\right)\end{array}$ & 3,0 & 4,0 & 2,4 & 6,0 & 2,5 & 3,7 & 6,3 \\
\hline $\begin{array}{c}\text { Average weight } \\
\left(W_{j}\right)\end{array}$ & 0,163 & 0,144 & 0,171 & 0,102 & 0,172 & 0,152 & 0,095 \\
\hline
\end{tabular}
THE FACTORS THAT SHAPE THE LEVEL OF MATERIAL INCENTIVES

As Table 4 shows, the factors that influence the level of material incentives are estimated in the following order: allowances for the work experience and labor intensity are in the first place (82.8 points), professional development is the second place (79.1 points); urgency allowance, quality of work are the third place (73.4 points); level of responsibility is the fourth place (69.7 points); allowance for the return on assets and scarcity if professions are very low evaluated by respondents: 49.4 and 45.6 points, respectively. In terms of ranking, the factors are as follows: the first place is the allowance for the work experience $(2,4)$, the second place is the labor intensity $(2,5)$; the third is the professional development $(3,0)$; the fourth is the allowance for urgency, quality of work $(3,7)$; the fifth place is responsibility level (4.0); the last two places are occupied by the indicators for the financial return on assets and the scarcity of professions as well, they are very low rated by the respondents: 6.0 and 6.3 points, respectively.

In addition to the above-mentioned absolute and average values of the relative importance of a factor, relative indicators, including average weight are also computed when processing the survey questionnaires.
The average weight $W_{j}$ of each factor (normalized value) is calculated by the formula (3):

$$
W_{j}=\frac{\sum_{i=1}^{m} W_{i j}}{\sum_{j=1}^{n} \sum_{i=1}^{m} W_{i j}}
$$

where $W_{i j}$ is the weight (normalized value) given by the $i$-th expert to the $j$-th factor; $W_{j}$ is the total weight assigned by experts to the $j$-factor.

The formula (4) for calculating the weight (normalized evaluation), assigned by the $i$-th expert to the $j$-th factor $\left(W_{i j}\right)$ :

$$
W_{i j}=\frac{\mathrm{C}_{i j}}{\sum_{j=1}^{n} \mathrm{C}_{i j}}
$$

According to the Table 3: $W_{11}=80:(80+70+100+$

\begin{tabular}{|c|c|c|c|c|c|c|c|}
\hline \multirow[b]{2}{*}{ 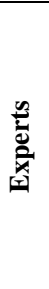 } & \multicolumn{7}{|c|}{ Factors } \\
\hline & 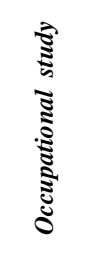 & 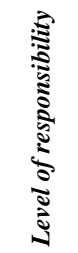 & 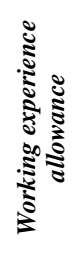 & 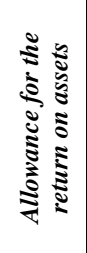 & 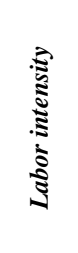 & 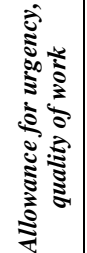 & 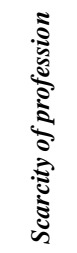 \\
\hline 1 & 0,154 & 0,135 & 0,192 & 0,115 & 0,173 & 0,154 & 0,077 \\
\hline 2 & 0,149 & 0,128 & 0,170 & 0,128 & 0,170 & 0,149 & 0,106 \\
\hline 3 & 0,160 & 0,140 & 0,200 & 0,060 & 0,180 & 0,180 & 0,080 \\
\hline 4 & 0,154 & 0,173 & 0,192 & 0,077 & 0,173 & 0,135 & 0,096 \\
\hline 5 & 0,191 & 0,128 & 0,149 & 0,085 & 0,213 & 0,149 & 0,085 \\
\hline 6 & 0,157 & 0,157 & 0,157 & 0,059 & 0,196 & 0,137 & 0,137 \\
\hline 7 & 0,163 & 0,163 & 0,184 & 0,122 & 0,143 & 0,163 & 0,061 \\
\hline 8 & 0,163 & 0,122 & 0,163 & 0,143 & 0,163 & 0,122 & 0,122 \\
\hline 9 & 0,196 & 0,130 & 0,152 & 0,087 & 0,174 & 0,196 & 0,065 \\
\hline 10 & 0,167 & 0,167 & 0,208 & 0,042 & 0,167 & 0,146 & 0,104 \\
\hline 11 & 0,189 & 0,170 & 0,113 & 0,132 & 0,151 & 0,113 & 0,132 \\
\hline 12 & 0,178 & 0,111 & 0,156 & 0,089 & 0,178 & 0,156 & 0,133 \\
\hline 13 & 0,167 & 0,125 & 0,188 & 0,083 & 0,167 & 0,167 & 0,104 \\
\hline 14 & 0,170 & 0,170 & 0,128 & 0,106 & 0,213 & 0,149 & 0,064 \\
\hline 15 & 0,167 & 0,167 & 0,119 & 0,095 & 0,214 & 0,167 & 0,071 \\
\hline 16 & 0,189 & 0,151 & 0,170 & 0,132 & 0,151 & 0,170 & 0,038 \\
\hline 17 & 0,159 & 0,159 & 0,182 & 0,091 & 0,182 & 0,136 & 0,091 \\
\hline 18 & 0,174 & 0,130 & 0,174 & 0,109 & 0,174 & 0,152 & 0,087 \\
\hline 19 & 0,140 & 0,140 & 0,200 & 0,100 & 0,160 & 0,160 & 0,100 \\
\hline 20 & 0,157 & 0,118 & 0,176 & 0,118 & 0,196 & 0,118 & 0,118 \\
\hline 21 & 0,160 & 0,200 & 0,160 & 0,060 & 0,200 & 0,120 & 0,100 \\
\hline 22 & 0,120 & 0,180 & 0,180 & 0,120 & 0,160 & 0,140 & 0,100 \\
\hline 23 & 0,114 & 0,159 & 0,159 & 0,091 & 0,182 & 0,182 & 0,114 \\
\hline 24 & 0,163 & 0,163 & 0,163 & 0,122 & 0,163 & 0,143 & 0,082 \\
\hline 25 & 0,182 & 0,127 & 0,182 & 0,127 & 0,127 & 0,182 & 0,073 \\
\hline 26 & 0,178 & 0,111 & 0,222 & 0,067 & 0,156 & 0,156 & 0,111 \\
\hline 27 & 0,180 & 0,120 & 0,180 & 0,120 & 0,200 & 0,140 & 0,060 \\
\hline 28 & 0,188 & 0,083 & 0,167 & 0,208 & 0,125 & 0,146 & 0,083 \\
\hline 29 & 0,160 & 0,140 & 0,180 & 0,040 & 0,180 & 0,180 & 0,120 \\
\hline 30 & 0,119 & 0,119 & 0,167 & 0,143 & 0,167 & 0,190 & 0,095 \\
\hline 31 & 0,159 & 0,159 & 0,182 & 0,114 & 0,136 & 0,136 & 0,114 \\
\hline 32 & 0,167 & 0,167 & 0,167 & 0,083 & 0,167 & 0,146 & 0,104 \\
\hline
\end{tabular}
$60+90+80+40)=1,139 ; W_{21}=70:(70+60+80+60$ $+80+70+50)=0,125$ etc. on other factors (Table 5 ).

TABLE V. MATRIX OF RELATIVE VALUE OF FACTORS 
The indicator $\sum W_{i j}$ is equal to the number of experts involved in the examination. Thus:

$$
\begin{aligned}
& \quad W_{l}=(0,154+0,149+0,160+0,154+0,191+0,157 \\
& +0,163+0,163+0,196+0,167+0,189+0,178+0,167 \\
& +0,170+0,167+0,189+0,159+0,174+0,140+0,157 \\
& +0,160+0,120+0,114+0,163+0,182+0,178+0,180 \\
& +0,188+0,160+0,119+0,159+0,167): 32=0,163 \text { etc. } \\
& \text { on other factors (Table } 4) .
\end{aligned}
$$

Assessment of the degree of consistency of experts' opinions is equally important for the scientific substantiation of the forecast according to expert methods. The conclusion to decide on the most appropriate factor is only possible if there is a certain level of consistency of experts.

The evaluation of the degree of consistency of the experts' opinions is estimated by the coefficient of concordance. In the presence of identical (standardized) ranks, the coefficient of concordance $\left(K_{k o n}\right)$ is calculated by the formulas (5-7):

$$
\begin{gathered}
K_{k o n}=\frac{12 \sum_{j=1}^{n} d_{j}^{2}}{m^{2}\left(n^{3}-n\right)-m \sum_{i=1}^{m} T_{i}} \\
d_{j}=S_{j}-\frac{\sum_{j=1}^{n} S_{i j}}{n} \\
\mathrm{~T}_{j}=\sum_{l=1}^{L}\left(t_{l}^{3}-t_{l}\right)
\end{gathered}
$$

where $l$ is the number of groups of related (same) ranks; $t l$ is the number of related ranks in each group.

According to the Rank Matrix (Table 3):

$l=32$, as each answer from 32 experts had standardized ranks of $(3 ; 3 ; 3) ;(8,5 ; 8,5) ;(1,5 ; 1,5) ; \ldots$.

Hence $t_{l 1}=2(3,5 ; 3,5) ; t_{l 2}=6(1,5 ; 1,5),(3,5 ; 3,5)$, $(5,5 ; 5,5) ; t_{l 3}=2(2,5 ; 2,5)$ etc. on other factors (Table 3$)$.

Here are the calculations on the formula (7):

$\sum T_{i}=\left(2^{2}-2\right)+\left(4^{2}-4\right)+\left(2^{2}-2\right)+\left(2^{2}-2\right)+\left(4^{2}-\right.$ 4) $+\left(5^{2}-5\right)+\left(3^{2}-3\right)+\left(6^{2}-6\right)+\left(2^{2}-2\right)+\left(3^{2}-3\right)+\left(4^{2}-\right.$ 4) $+\left(4^{2}-4\right)+\left(3^{2}-3\right)+\left(2^{2}-2\right)+\left(3^{2}-3\right)+\left(4^{2}-4\right)+\left(6^{2}-\right.$ $6)+\left(3^{2}-3\right)+\left(6^{2}-6\right)+\left(4^{2}-4\right)+\left(4^{2}-4\right)+\left(4^{2}-4\right)+$ $\left(6^{2}-6\right)+\left(6^{2}-6\right)+\left(4^{2}-4\right)+\left(4^{2}-4\right)+\left(2^{2}-2\right)+\left(3^{2}-\right.$ $3)+\left(4^{2}-4\right)+\left(6^{2}-6\right)+\left(4^{2}-4\right)=392$

To determine the coefficient of concordance the data from Table 3 are used. Intermediate calculations are provided in table. 6 .

The coefficient of according to the formula (5) is:

$$
\mathrm{K}_{k o n}=\frac{12 * 84405}{32^{2}\left(7^{3}-7\right)-32 * 392}
$$

\begin{tabular}{|c|c|c|c|c|c|c|c|c|}
\hline \multirow[b]{2}{*}{ 苞 } & \multicolumn{7}{|c|}{ Factors } & \multirow[b]{2}{*}{$\sum$} \\
\hline & 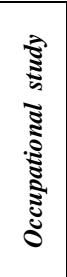 & 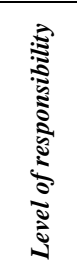 & 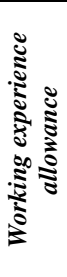 & 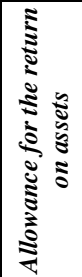 & 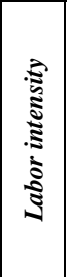 & 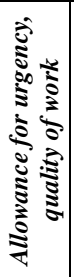 & 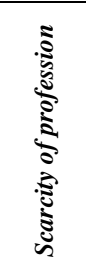 & \\
\hline $\begin{array}{c}\text { Total } \\
\operatorname{ranks}\left(S_{j}\right)\end{array}$ & 94,5 & 128,5 & 76,5 & 191,5 & 79 & 117 & 200 & 887 \\
\hline $\begin{array}{l}\text { Deviation } \\
\text { from the } \\
\text { average }\left(d_{j}\right)\end{array}$ & 67 & 101 & 49 & 164 & 51,5 & 89,5 & 172,5 & - \\
\hline$d_{j}^{2}$ & 4489 & 10201 & 2401 & 26896 & 2652 & 8010 & 29756 & 84406 \\
\hline
\end{tabular}

The greater the value of the coefficient of concordance, the higher the degree of consistency of the experts' opinions. If $K_{k o n}=1.0$, then there is complete consistency of opinions of experts; if $K_{k o n}=0$, the consistency is completely absent. As it is shown, $K_{k o n}=$ 2.96. This means complete consistency of opinions of experts, so, the study is reliable.

TABLE VI. INTERMEDIATE CALCULATIONS FOR DETERMINING THE COEFFICIENT OF CONCORDANCE BASED ON THE RANK MATRIX DATA

Thus, the method of conducting research based on the Delphi expert evaluation method established the average weight of each factor, which, according to the interviewed experts, should influence the level of material incentives. Of the seven factors, two are rated very low, so we suggest them not be taken into account (allowance for the return on assets and the scarcity of professions). We propose to introduce the other five factors by the values of their average weights as incremental coefficients for the calculation of workers' wages formulas (8-9):

$$
W W=W R *\left(1+\sum W_{A R}\right)
$$

where $W R$ is the wage rate, $\mathrm{UAH} ; W_{A R}$ is the allowance ratios.

$$
\sum W_{A R}=W_{1}+W_{2}+W_{3}+W_{4}+W_{5}
$$

where $W_{1}$ is Occupational study; $W 2$ is the level of responsibility; $W_{3}$ is the work experience allowance; $W_{4}$ is labor intensity; W5 is the allowance for urgency, quality of work.

$\sum W_{A R}=0,163+0,144+0,171+0,172+0,152=0,802$

To approve the proposed methodological approach, a private agricultural enterprise named after Frunze of the Zachepylivskyi district, Kharkiv region was celected. The calculation of material incentives using increasing coefficients calculated by the Delphi method are provided in table. 7

TABLE VII. CALCULATION OF MATERIAL INCENTIVES FOR AGRICULTURAL WORKERS AT THE PAE NAMED AFTER FRUNZE OF ZACHEPYLIVSKY DISTRICT, KHARKIV REGION

\begin{tabular}{|c|c|c|c|}
\hline \multirow{2}{*}{ Position } & \multirow{2}{*}{$\begin{array}{c}\text { Average salary, } \\
\text { UAH }\end{array}$} & \multicolumn{2}{|c|}{ Material incentives, UAH } \\
\cline { 3 - 4 } & Overall amount & $\begin{array}{c}\text { Increase in } \\
\text { wages }\end{array}$ \\
\hline Milkmaid & 5857 & 10554 & 4697 \\
\hline Mechanic & 5946 & 10714 & 4768 \\
\hline Agronomist & 8873 & 15989 & 7116 \\
\hline
\end{tabular}


As the table shows, employees of the PAE named after Frunze of Zachepylivsky district, Kharkiv region will receive the following material incentives: almost twice the salary increase $(1,802)$.

Depending on the financial condition of the company and other factors, executives can adjust the number of increasing coefficients by selecting several of them.

\section{CONCLUSIONS}

Thus, when talking about the innovative development of agricultural enterprises it is necessary to take into account the peculiarities of this economic system. The agricultural product nomenclature has remained virtually unchanged for millennia: grain, vegetables, sugar, oil, fruits, berries, milk, meat, eggs, wool, etc. That is, agriculture does not have to replace these products with others. Therefore, the innovative development of agricultural enterprises as an economic system has two main directions: the improvement of production technologies and the improvement of quality of labor resources. In our opinion, an increase in the level of intellectualization of labor resources should become the basis for the innovative development of agricultural enterprises. That is, increasing the share of mental functions in the structure of labor efforts of employees while using different material incentives, will allow achieving an increase in the volume of products produced, which will favor the increase of profit of agricultural enterprises. The authors propose a methodical approach to determining material incentives for agricultural workers, which is based on the calculation of wages with increasing coefficients. These coefficients are calculated based on expert evaluations determined by the Delphi expert evaluation method.

\section{REFERENCES}

[1] M. Yi. Malik, O. G. Shpykulyak, and O. M. Suprun, "Development of entrepreneurial activity in the agrarian sector: macroeconomic aspect", Uzhgorod University Scientific Bulletin, Economy Series, vol. 2, no. 1 (49), 2017. [Online]. Available: http://www.visnykekon.uzhnu.edu.ua/images/pubs/49_2/49_3237.pdf. Accessed on: September, 2019.

[2] P. R. Gregory, and R. C. Stuart, "The Global Economy and its Economic Systems", South-Western College Pub., pp. 30, 2013.

[3] V. Holesovsky, Economic Systems: Analysis and Comparison, New York: McGraw-Hill Book Co., pp. 495, 1977

[4] P. K.Wong, Y. P. Ho, and E. Autio, "Entrepreneurship, Innovation and Economic Growth: Evidence from GEM Data.", Small Business Economics, no. 24 (3), pp 335-350, 2005

[5] N. J. Foss, and T. Saebi, "Fifteen Years of Research on Business Model Innovation: How Far Have We Come, and Where Should We Go?", Journal of Management, no. 43(1), pp. 200-227, 2017.

[6] Jari J. Ritsila, "Regional differences in environments for enterprises", Entrepreneurship \& Regional Development, no. 11:3, pp. 187-202, 1999. Doi: $10.1080 / 089856299283164$.
[7] C. Kwong, M. Tasavori, and C. W. Cheung, "Bricolage, collaboration and mission drift in social enterprises", Entrepreneurship \& Regional Development, no. 29:7-8, pp. 609638, 2017. Doi: 10.1080/08985626.2017.1328904.

[8] J. Li, J. Qu, and Q. Huang, "Why are some graduate entrepreneurs more innovative than others? The effect of human capital, psychological factor and entrepreneurial rewards on entrepreneurial innovativeness", Entrepreneurship \& Regional Development, no.30:5-6, pp. 479-501, $2018 . \quad$ Doi: 10.1080/08985626.2017.1406540.

[9] J. O. Rypestol, and J. Aarstad, "Entrepreneurial innovativeness and growth ambitions in thick vs. thin regional innovation systems", Entrepreneurship \& Regional Development, no. 30:5-6, pp. 639661, 2018. Doi: 10.1080/08985626.2018.1444104.

[10] I. B. Weiner, Handbook of psychology: Industrial and organizational psychology, V. 12. New Jersey: John Willey \& Sons, Inc., p. 649, 2014. [Online]. Available: http://simbi.kemenag.go.id/pustaka/images/materibuku/Wiley.Hand book.of.Psychology.Volume-12.pdf. Accessed on: September, 2019

[11] E. Papasotiriou, G. Sidiropouos, S. Ntanos, M. Chalikias and M. Skordoulis, "The relationship between professional burnout and satisfaction: A case study for physical education teachers in a Greek urban area", Serbian Journal of Management, no. 13 (2), 2018.

[12] Ch. Ktena, G. Sidiropoulos, M. Chalikias, S. Ntanos andG. Kyriakopoulos, "The contribution of mentoring on employee's career development with non-dependent work relation: The case of the networking company LR health \& beauty systems", Academy of Strategic Management Journal, no. 17 (1), 2018.

[13] E. Wasito, "The effect of material incentives on work motivation and employee performance of STIE Ekuitas Bandung", Unpublished Thesis. 2014.

[14] R. R. Novianty. S. N. Evita, "Financial Incentives: The Impact on Employee Motivation", Academy of Strategic Management Journal. Vol: 17, Issue: 6, 2018. [Online]. Available: https://www.abacademies.org/articles/financial-incentives-theimpact-on-employee-motivation-7728.html. Accessed on: September, 2019.

[15] Global innovation index. [Online]. Available: https://www.globalinnovationindex.org/analysis-indicator. Accessed on: September, 2019.

[16] Research and development in 2018, State Statistics Service of Ukraine. [Online]. Available: http://www.ukrstat.gov.ua. Accessed on: September, 2019.

[17] Scientific and Innovative Activity of Ukraine: Statistical Collection Editor in chief O. O. Karmazina, State Statistics Service of Ukraine, Kyiv, pp. 111, 2018. [Online]. Access mode: http://www.ukrstat.gov.ua/druk/publicat/kat_u/2018/zb/09/zb_nauka _2017.pdf. Accessed on: September, 2019.

[18] Activities of business entities: statistical compilation, edited by M. Kuznetsova, State Statistics Service of Ukraine, Kyiv, pp. 127, 2018. [Online]. Access mode: http://www.ukrstat.gov.ua/druk/publicat/kat_u/2018/zb/09/zb_nauka _2017.pdf. Accessed on: September, 2019.

[19] M. A. Andreev, "Financial incentives to increase the level of intellectualization of work as a prerequisite for economic growth: a conceptual aspect", in Problems and Prospects of Innovation Activity in Ukraine: XI International Business Forum, Kyiv, 2018, p. 13.1 [Online]. Available: https://knute.edu.ua/file/ODc0Mw==/53ec8a30e688165ab46cb806c 8831614.pdf. Accessed on: September, 2019. 